J. Perinat. Med. 15 (1987) 73

\title{
Oversized infant of diabetic mother: its cause and prevention*
}

\author{
Sebastiano Grasso and Gian Domenico Roversi
}

Institute of Anatomy and Histopathology, University of Catania, Italy

\section{Introduction}

According to the hyperglycemia-hyperinsulinism hypothesis [12], fetal macrosomia in diabetic pregnancy results from a series of events triggered by maternal hyperglycemia. Excessive maternal glucose crossing the placenta causes fetal hyperglycemia and thus overstimulates the fetal pancreas. Fetal hyperinsulinemia, plus a large supply of glucose substrate, greatly enhances protein, lipid and glycogen synthesis and acts as a strong stimulant for growth of fetal tissue. Over the years, this hypothesis has been broadened to include other insulin-dependent fuels as maternal stimuli of fetal macrosomia [4]. These are mainly free fatty acids (FFA) and aminoacids, which are increased in the maternal circulation due to inadequate insulin release and are more available to the conceptus. FFA are an addidional substrate for tissue growth. Aminoacids, in addition to glucose, favor maturation of beta-cells and stimulate insulin release $[6,7,8]$.

Prevention of fetal macrosomia, whether it is due only to glucose or to other fuels too, depends on correction of the maternal metabolic derangement during pregnancy. The better maternal diabetes is compensated, the nearer to normal fetal development will be and the lower the risk of fetal overweight. In fact, in the last

\footnotetext{
* Presented at the "Third International Colloquium on Carbohydrate Metabolism in Pregnancy and the Newborn", Aberdeen, Great Britain, April 11-13, 1983
}

\section{Curriculum vitae}

Sebastiano Grasso was graduated in 1956 from Catania University, Italy, where at present he is a professor of "Anatomia ed Istologia Patologica". He spent several years at Montreal University, Canada (1959-61) and California University (1961-65), San Francisco where he studied experimental medicine and endocrinology. Since returning to Italy his major interest has been the morphology and pathophysiology of the fetal and neonatal endocrine pancreas.

ten years a policy of tighter control of diabetes has been in general adopted, and fetal macrosomia has declined. However, both the mean birth weight and the percentage of oversized babies are still high, much higher than normal, in all case studies reported so far.

In a recent clinical study with a small number of cases [18], the pregnant diabetics with strictly regulated blood sugar levels gave birth to growth retarded infants. The authors explained this as follows: in pregnant diabetics, for some still unknown cause, fetal development is inhibited in the early weeks of gestation. Later in pregnancy, exaggerated activity of the glucoseinsulin system more than compensates for the delayed initial growth, bringing about fetal macrosomia. When there is strict metabolic con- 
trol of the maternal illness, the late macrosomic stimulus is removed and the negative effect of the delayed initial growth is allowed to manifest itself, causing the fetus to be growth retarded [18].

The aim of our study was to see whether or not strict metabolic control of the diabetic mother really does prevent fetal macrosomia and, if so, whether this prevention results in normal or in retarded fetal growth.

\section{Material and methods}

The birth weights of infants of the Milan series of pregnant diabetics $[14,15]$ have been analyzed. Both pregnant women with gestational diabetes (White's Class A) and those with clinical diabetes (Classes $\mathrm{B}-\mathrm{F}$ ) had been treated with the maximal tolerated dose (MTD) of insulin. A detailed description of this therapeutic regimen and the perinatal results have already been published $[14,15]$.

The population consisted of 484 infants with 53 cases excluded because there were factors in addition to maternal diabetes that may have influenced fetal development (toxemia, congenital malformations, etc.). The remaining 431 infants were distributed into groups according to the severity of maternal diabetes: 217 , gestational diabetes (Class A); 123, clinical diabetes without vascular complications (Classes B and C); 91, clinical diabetes with vascular complica- tions (Classes D, E and F). Infants of Class E were also considered separately. They were born to mothers with gestational or clinical diabetes and vascular pathology affecting only the pelvic vessels.

\subsection{Comparison with the birth weights of con- trol newborns}

The control group consisted of newborns whose weights are generally assumed to be representative of our region (Northern Italy) [5]. This series was matched for sex and gestational age to each of the diabetic groups with which it was being compared. The averages (table I) and the centile distributions (figure 1) of the birth weights were compared. The data were analyzed with the Student t-test and the Kolmogorov-Smirnov test. Data for centile distributions are plotted on probability paper (figure 1).

\subsection{Comparison with the birth weights of in- fants born in previous pregnancies to the multi- parae in the case study}

The multiparae (para II, 60; para III, 21) included in the analyses met the following criteria:

- delivery time in the present pregnancy $>36$ th week;

- in the present pregnancy, maternal diabetes controlled with MTD insulin within the 30th week;

Table I. Birth weights of infants of diabetic mothers and control infants.

\begin{tabular}{|c|c|c|c|c|c|c|}
\hline \multicolumn{3}{|c|}{ Infants of diabetic mothers } & \multirow[t]{2}{*}{$\Delta(\mathrm{g})$} & \multicolumn{3}{|c|}{ Control newborns } \\
\hline $\begin{array}{l}\text { White's } \\
\text { Classes }\end{array}$ & $\begin{array}{l}\text { Number } \\
\text { of infants }\end{array}$ & $\begin{array}{l}\text { Weight (g) } \\
\bar{X} \pm S D\end{array}$ & & $\begin{array}{l}\text { Number } \\
\text { of infants }\end{array}$ & $\begin{array}{l}\text { Weight (g) } \\
\bar{X} \pm S D\end{array}$ & $\mathrm{p}$ \\
\hline A & 217 & $3125+471$ & -46 & 8166 & $3171 \pm 472$ & NS \\
\hline $\mathrm{B}, \mathrm{C}$ & 123 & $3209 \pm 566$ & +46 & 7902 & $3163 \pm 486$ & NS \\
\hline $\mathrm{D}, \mathrm{E}, \mathrm{F}$ & 91 & $2925 \pm 596$ & -177 & 7964 & $3102 \pm 519$ & $<0.01$ \\
\hline $\mathrm{E}$ & 41 & $2935 \pm 507$ & -195 & 6089 & $3130 \pm 490$ & $<0.05$ \\
\hline All Classes & 431 & $3106 \pm 537$ & -50 & 8308 & $3156 \pm 485$ & $<0.05$ \\
\hline
\end{tabular}

p: Student t-test

NS: Not statistically significant

$\Delta$ : Difference in weight (in $\mathrm{g}$ ) between infants of diabetic mother and normals 


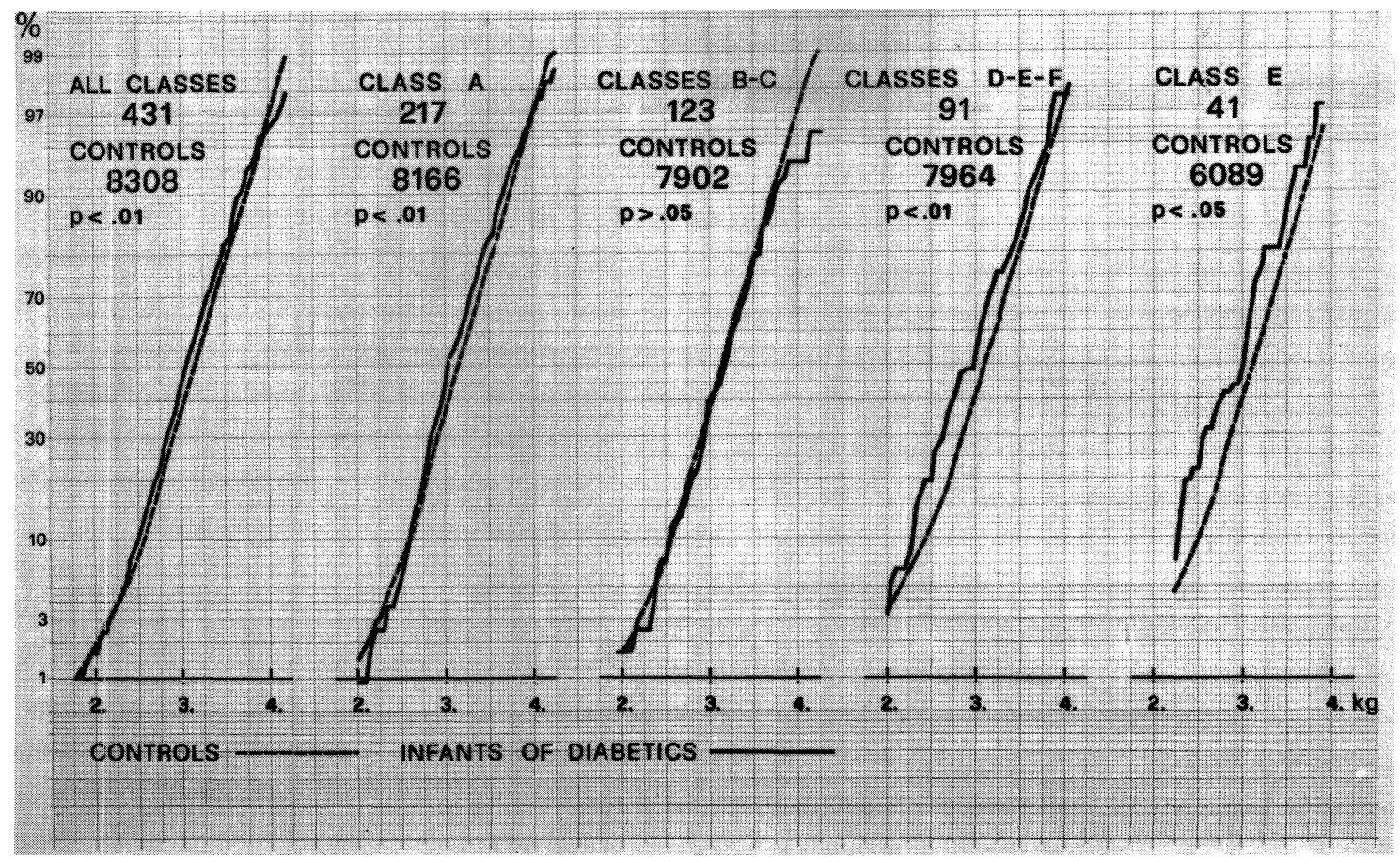

Figure 1. Comparison of birth weight centiles between infants of diabetics and control newborns (KolmogorovSmirnov test).

- delivery during the last month of gestation in previous pregnancies;

- no treatment with MTD insulin in the previous pregnancies;

- previous pregnancies and delivery not followed in our Center.
The mean birth weights in the last pregnancy were compared with the mean birth weights in the previous pregnancies, namely the first in para II and the second in para III (t-test for paired data) (table II). The pairs of siblings of the two pregnancies were also compared and

Table II. Multiparae (para II, III) pregnant diabetics: birth weight of infants in successive pregnancies.

\begin{tabular}{|c|c|c|c|c|c|c|c|}
\hline \multirow[t]{2}{*}{$\begin{array}{l}\text { Withe's } \\
\text { Classes }\end{array}$} & \multirow[t]{2}{*}{$\begin{array}{l}\text { Number } \\
\text { of infants }\end{array}$} & \multicolumn{5}{|c|}{$\begin{array}{l}\text { Weight of infants (g) } \\
\bar{X} \pm \text { SD }\end{array}$} & \multirow{2}{*}{$\begin{array}{l}\text { Gestational } \\
\text { age (weeks) } \\
\bar{X} \pm S D\end{array}$} \\
\hline & & $1 \mathrm{st}$ & $\Delta(\mathrm{g})$ & 2nd & $\Delta(\mathrm{g})$ & $3 \mathrm{rd}$ & \\
\hline $\begin{array}{l}\text { A } \\
\text { B,C } \\
D, E, F\end{array}$ & $\begin{array}{l}30 \\
20 \\
10\end{array}$ & $\begin{array}{l}3835 \pm 534 \\
4033 \pm 648 \\
3345 \pm 641\end{array}$ & $\begin{array}{l}-620 \\
-696 \\
-480\end{array}$ & \begin{tabular}{|l|}
$3215 \pm 324$ \\
$3337 \pm 349$ \\
$2865 \pm 406$ \\
\end{tabular} & & & $\begin{array}{l}38.9 \pm 0.9 \\
39.0 \pm 1.2 \\
39.2 \pm 1.1\end{array}$ \\
\hline $\begin{array}{l}\mathrm{A} \\
\mathrm{B}, \mathrm{C}\end{array}$ & $\begin{array}{l}10 \\
11\end{array}$ & $\begin{array}{l}3520 \pm 496 \\
3886 \pm 548\end{array}$ & $\begin{array}{l}+200(\mathrm{NS})^{\circ} \\
+197(\mathrm{NS})^{\circ}\end{array}$ & $\begin{array}{l}3740 \pm 615 \\
4083 \pm 511\end{array}$ & $\begin{array}{l}-539 \\
-874\end{array}$ & $\begin{array}{l}3210 \pm 266 \\
3209 \pm 255 \\
\end{array}$ & $\begin{array}{l}39.3 \pm 1.2 \\
39.2 \pm 1.9 \\
\end{array}$ \\
\hline
\end{tabular}

$\circ: \mathrm{t}$-test for paired data

NS: Not statistically significant

In the boxes: Maternal diabetes compensated with insulin MTD 
graphs were constructed of the weight differences between the second and the first versus the weight of the first sibling (figures 2 and 3). The regression line was calculated and the F-test used for statistical analyses. For para III the birth weights of infants born from the first and the second pregnancies were also compared (table II, figure 3). Since the patients were not treated with MTD insulin in either of the two pregnancies, we expected to find no differences between the birth weights of these infants.

\section{Results}

\subsection{Comparison with the birth weights of con- trol newborns}

As shown in table I, the mean birth weight of the infants of Class A was $46 \mathrm{~g}$ less than that for the controls, while the mean birth weight of infants of Classes B and C was $46 \mathrm{~g}$ more, neither difference being statistically significant. The mean birth weight of infants of Classes D, $\mathrm{E}$ and $\mathrm{F}$ was $177 \mathrm{~g}$ less than in the control
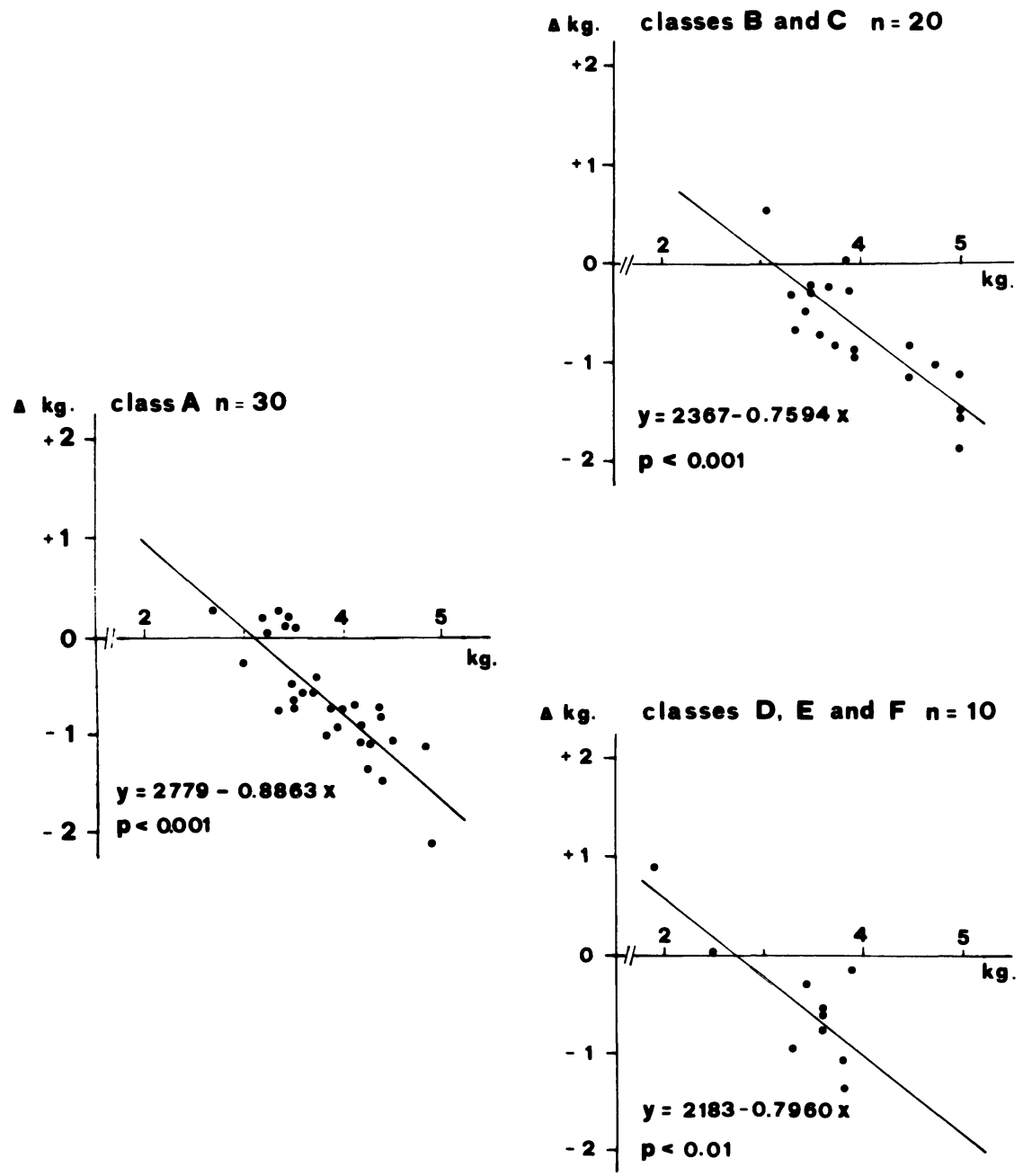

Figure 2. Comparison of the birth weight of infants born to para II diabetic women. MTD insulin administered only in the second pregnancy. Comparison of weights of the two siblings. On the horizontal axis, the weight of the 1st sibling, on the vertical axis the difference in weight between the two siblings (2nd minus 1st). F-test. 
group $(p<0.01)$ and that of infants of Class E was $195 \mathrm{~g}$ less $(p<0.05)$. The birth weight of all infants was $50 \mathrm{~g}$ less than in the control group and the difference was statistically significant $(\mathrm{p}<0.05)$.

More detailed information is obtained from the comparison of the centiles of the infants' weights (figure 1). There was a small difference between the centiles of weights of all the infants studied and those of the controls. The two plots of centile distributions are close, but the difference is significant $(p<0.01)$. The weight differences fluctuate around $70 \mathrm{~g}(2 \%)$ along the plots. When comparing Class $\mathrm{A}$ and Classes $\mathrm{B}$ and $\mathrm{C}$ with the controls, the differences between the lines of centiles are slight (Class A) $(p<0.01)$ or almost non-existent (Classes B and C) $(p>0.05)$. When Class $A$ is compared with the controls, the difference in weight in-
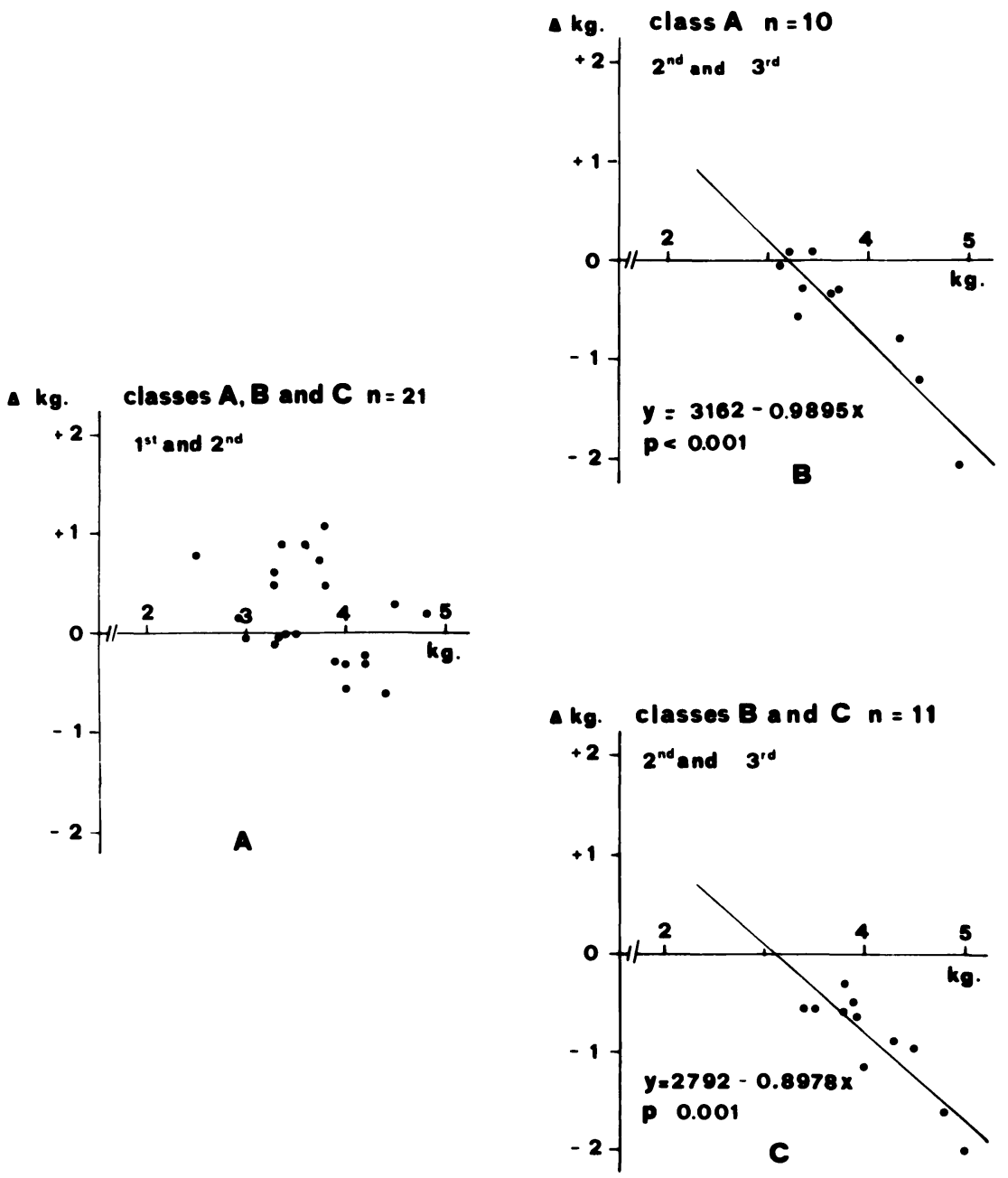

Figure 3. Comparison of the birth weight of infants born to para III diabetic women. MTD insulin administered only in the third pregnancy.

A) Comparison of weights between the 1st and the 2nd siblings. Horizontal and vertical axis as in figure 2 .

B, C) Comparison of weights between the 2 nd and the 3rd siblings. On the horizontal axis, the weight of the 2 nd siblings, on the vertical axis the difference in weight between the two siblings (3rd minus 2nd). F-test. 
creases from $7 \mathrm{~g}(0.3 \%)$ to $87(2 \%)$, going from centiles 12.5 to 87.5 . The weight difference between Classes B and C and controls is only a few grams, reaching a maximum of $1 \%$. There is marked difference between the centiles of weight for infants in Classes D, E and F and those in the control group. In fact, the two plots of centile distribution are well separated $(p<0.01)$ and the weights of Classes D, E and $\mathrm{F}$ are much lower all along the line. The difference increases from the higher to the lower centiles and remains around 220-250 g below the 50th centile. There is a great difference between Class $\mathrm{E}$ and the controls $(\mathrm{p}<0.05)$.

\subsection{Comparison with the birth weights of the infants born in previous pregnancies to multipa- rae in the case study}

Any differences there were between the birth weights in the present and the previous pregnancy may have been due not only to the strict control of maternal diabetes in the present pregnancy, but also to differences between the groups in sex and gestational age of the fetus and maternal parity. However, the groups of infants compared were homogeneous in terms of sex distribution. Differences of sex between one sibling and another, e. g. 1st male sibling and 2 nd female sibling, were counterbalanced by differences of sex in the opposite direction, i. e. 1 st female and 2 nd male. The other two variables should have had positive effects, i. e. favoring a higher birth weight of the infant of the present pregnancy. In fact; we waited for spontaneous labor (mean gestational age 39 week in every Class, table II), while delivery had probably been induced in the preceding pregnancy, which is common practice in diabetics, except for those of Class A. As regards the influence of parity, the birth weight tends to increase in subsequent pregnancies after the first, and the present pregnancy of our multiparae was, obviously, the latest one. Accordingly, a lower birthweight of the last infant than of the preceding would not only be attributable to the strict control of maternal diabetes, but even more significant.
In the para II of every Class, the mean birth weight fell from the 1 st to the 2 nd pregnancy (table II). The mean birth weights of the first infants in Class A (3835 g) and Classes B and C $(4033 \mathrm{~g})$ were higher than expected at 40 weeks', whereas, the mean birth weights in the second (3215 $\mathrm{g}$ and $3337 \mathrm{~g}$ ) resembled those of normal newborns at $38-39$ weeks. In diabetics with vascular complications (Classes $\mathrm{D}, \mathrm{E}$ and F), the mean birth weight of the first infants was similar to that of normal newborns, but the mean birth weight of the second (2865 g) was lower than expected at 38-39 weeks.

For the para III of Class A and Classes B and $\mathrm{C}$ (table II), the mean birth weights were higher than expected in the first infants $(3520 \mathrm{~g}$ and $3886 \mathrm{~g}$ ) and still high in the second pregnancy (mothers not controlled with MTD insulin). The weight reduction in the third infants (mothers now compensated during pregnancy with MTD insulin) was similar to that observed in the para II.

As shown in figures 2 and 3 (B and C), the weight reduction in infants whose mothers were treated with the MTD insulin is directly proportional to the birth weight of the preceding sibling. The correlation is statistically significant for every comparison. On the contrary, no correlation could be observed when maternal diabetes was not strictly controlled. In fact, in the second pregnancy of para III the tendency toward overweight infants observed in the preceding pregnancy was confirmed and even worsened (figure 3, A). From the graphs we can observe that there is an end-point for weight reduction in the latest sibling (maternal diabetes strictly compensated), represented by the intercept of the regression line on the horizontal line. In fact, at this point the regression line, running from right to left, enters the quadrant in which the weight difference has a positive sign, i. e. the weight of the latest sibling, instead of being less, increases. At this intercept, in pregnant diabetics without vascular complications the birth weights were similar to those of control newborns of the same gestational age (para II: Class A 3136 g, B and C 3117 g; para III: Class A $3195 \mathrm{~g}, \mathrm{~B}$ and C $3110 \mathrm{~g}$ ). On the 
contrary, in the para II with vascular complications the end-point for the weight reduction of the latest sibling is a weight $(2742 \mathrm{~g})$ which is lower than that of control newborns.

\section{Comment}

The results of this study clearly demonstrate that fetal macrosomia can be prevented in pregnant diabetic women. In fact, except for infants of pregnant diabetics with vascular complications, there was no significant difference between the averages and the centile distributions of weights of controls and infants of diabetics mothers (table I, figure 1). Our results do not indicate that there is any risk of fetal growth retardation as a consequence of the compensation of maternal diabetes itself [18]. It must be emphasized that our pregnant diabetics were those most likely to give birth to growthretarded infants, since the dose of insulin they received in pregnancy was the maximum tolerated. It is particularly noticeable for the multiparae that for the birth weight decrease in the latest infants, as compared with the birth weights of the preceding siblings (figures 2 and 3 ), there is a weight-limit under which the weight decrease due to maternal metabolic compensation does not go, this limit corresponds to the normal birth weight for infants of mothers without vascular complications.

As shown by the high incidence of fetal macrosomia in patients with gestational diabetes, even a minimal disturbance of fuel metabolism in the mother is sufficient to cause an excess of substrate to the fetus demonstrating, that normal fetal growth requires excellent control of diabetes in pregnancy. In our case study this was secured throughout pregnancy by administration of the MTD of insulin. In fact, maternal blood glucose was normalized, even though this is not the specific purpose of this therapeutic regimen [16]. It is noticeable that in multiparae (table II) the birth weights of the infants in the latest pregnancy were drastically smaller than the birth weights of the infants in their previous pregnancies (no MTD insulin). Moreover, the reduction was greater, the greater the birth weight of the corresponding sibling in the previous pregnancy (figures 2 and 3 ). This suggests that the control of the weight increase that can be obtained by compensation of maternal diabetes is proportional to the risk of fetal macrosomia.

All the studies published have shown that the high incidence of large babies in gestational diabetic women is not significantly decreased when these patients are treated only by diet. Even though their metabolic abnormality is slight, its correction requires insulin therapy, and we report here for the first time the normalization of the birth weight of the infants of gestational diabetic mothers (table I, figure 1). Substitution of a clinical index for blood glucose in the regulation of insulin dosage makes the scheme of insulin administration at the MTD particularly suitable for the treatment of these patients.

In our population the only tendency to undersized babies was seen in diabetic pregnancies with vascular complications (table I, figure 1). This could have been anticipated since placental blood flow, on which the access of substrates to the fetus depends, is greatly impaired in these patients. In this study, we saw that even vascular damage limited to the pelvic vessels (Class E) could greatly retard fetal growth (table I, figure 1). This risk has not been remarked upon in the literature, because pelvic vascular pathology is usually disregarded and the patients remain undifferentiated among pregnant diabetics of Classes $\mathrm{A}-\mathrm{C}$. Their frequency seems to be high. If, in the present study, we eliminate those infants in Classes $\mathrm{A}-\mathrm{C}$ whose mothers did not have pelvic vessel examinations and redistribute Class $\mathrm{E}$ infants into these Classes, the incidence of these infants in Class A was $17 \%$ and in Classes B and C $12 \%$.

It has been shown that in pregnant diabetics there is no correlation between infant birth weight and maternal blood glucose level [9, 11] and, in addition, that infants of diabetic mothers, even though oversized for gestational age, are not as large as they should be according 
to their hyperinsulinism [13]. This would imply that fetal macrosomia cannot be due only to maternal hyperglycemia and fetal hyperinsulinism and that it could not be prevented only by strict control of maternal diabetes. We believe that the lack of correlation might be explained by the results of recent animal studies [3]. It has been shown that direct fetal insulin infusion is accompanied by an increase in umbilical glucose uptake, a decrease in fetal plasma glucose concentration and a progressive decline in fetal blood oxygen content. Up to now, the data obtained in these studies has been used to explain sudden fetal death in diabetics during the last month of pregnancy $[1,3]$. Nevertheless, it seems reasonable to believe that these episodes of fetal hypoxia could vary in degree and duration and not always result in fetal death. During these episodes, the fetus needs a marked increase in the glycolysis rate, since the amount of energy released during the conversion of glucose to lactic acid is only a fraction of that released in its complete oxidation to carbon dioxide and water [17]. Accordingly, the hypoxic fetus would have to metabolize much more glucose to produce the same amount of energy and the burning of some of the excess glucose transferred to the fetus from the diabetic mother could slow down fetal overgrowth. As a result, in non-controlled diabetic pregnancy the birth weight would not correlate with the maternal blood sugar level and, even though it is high for gestational age, it will always be lower than expected from the degree of fetal hyperinsulinism.

There are many indirect proofs of fetal hypoxia in diabetic pregnancy $[10,19,20]$. However, direct evidence has been obtained only by BERGLUND and ZETTERSTRÖM [2], who have found the oxygen content in the umbilical cord to be below normal limits in infants of diabetics born by cesarean section. If future studies confirm that fetal hyperinsulinism causes hypoxia as it does in experimental animals, this would be a further reason for strictly controlling maternal diabetes and all aspects of fetal overgrowth, including those which seem at present to be inconsistent with the hyperglycemia-hyperinsulinism theory, will be explained without invoking any mechanism beyond that encompassed by the theory itself.

\section{Summary}

In this study the birth weights of 431 infants of diabetic mothers of the Milan series $[14,15]$ have been compared with the birth weights of infants of a control group [5]. The averages and the centile distributions of weights of infants of gestational diabetic mothers (Class A) and of diabetic mothers without vascular complications (Classes B and C) did not differ substantially from those of control newborns (table I, figure 1). This confirms the clinical indication, based on the hyperglycemia-hyperinsulinism theory [12] that fetal macrosomia can be prevented provided maternal metabolism is strictly controlled. In this series insulin was administered at the maximal tolerated dose (MTD), a therapeutic regimen that provides excellent metabolic control of the mother $[14,15,16]$. In multiparae, the birth weights of the infants of the latest pregnancy were drastically lower than the birth weights of the infants in their previous pregnancies (without MTD insulin) (table II). Our results do not confirm the recent hypothesis [18] that pregnant diabetics with strict metabolic control during pregnancy generally give birth to growth retarded in- fants. The MTD of insulin has also been administered to gestational diabetic mothers, and fetal macrosomia was prevented (table I, figure 1). This confirms the opinion of those who believe that a diet-regimen must be accompanied by insulin administration to correct the slight metabolic abnormality of these patients. As would be expected because of placental insufficiency, infants of patients with vascular complications, including those who have only calcifications of the pelvic vessels (White' Class E), were growth retarded (table I, figure 1). The risk of fetal growth retardation in Class $\mathrm{E}$ has not been remarked upon in the literature, since pathology of pelvic vessels is usually disregarded and the patients remain undifferentiated among Classes $\mathrm{A}-\mathrm{C}$. The possibility to prevent fetal macrosomia with a strict control of maternal diabetes has been questioned because of the lack of correlation between fetal macrosomia and the degree of maternal hyperglycemia $[9,11]$ and of fetal hyperinsulinism [13]. We postulate that, if fetal hyperinsulinism causes hypoxia, as it does in experimental animals [3], the lack of correlation may be due to the fetal hyperinsulinism itself.

Keywords: Diabetes mellitus in pregnancy, fetal macrosomia, gestational diabetes, hyperglycemia-hyperinsulinism theory, maximal tolerated dose of insulin. 


\section{Zusammenfassung}

\section{Makrosomie bei Neugeborenen diabetischer Mütter - Ursachen und Prävention}

In der vorliegenden Studie werden die Geburtsgewichte von 431 Kindern von Diabetikerinnen aus der Mailänder Untersuchungsreihe $[14,15]$ verglichen mit den Geburtsgewichten von Kindern einer Kontrollgruppe [5]. Die Mittelwerte und die Perzentilenverteilung der kindlichen Geburtsgewichte bei Gestationsdiabetes (Klasse A) und mütterlichem Diabetes ohne vaskuläre Komplikationen (Klasse B und C) unterschieden sich nicht wesentlich von denen der Kontrollgruppe (Tabelle I, Abb. 1). Basierend auf der Hyperglykämie-Hyperinsulinismus-Theorie [12] wird die klinische Vorstellung, daß bei strenger Stoffwechselführung eine fetale Makrosomie vermieden werden kann, bestätigt. Die Patientinnen erhielten Insulin bis zur maximal tolerierten Dosis (MTD), und unter dieser Therapie war die Stoffwechsellage optimal [14, $15,16]$. Bei Mehrgebärenden war das kindliche Geburtsgewicht nach Insulingabe in der Schwangerschaft erheblich niedriger als die Geburtsgewichte nach vorangegangenen Schwangerschaften ohne Therapie (Tabelle II). Unsere Ergebnisse bestätigen nicht die kürzlich aufgestellte Hypothese [18], nach der schwangere Diabetikerinnen mit strenger Stoffwechselführung generell wachs- tumsretardierte Kinder zur Welt bringen. Auch Frauen mit Gestationsdiabetes wurden mit Insulin bis zur MTD therapiert; eine fetale Makrosomie wurde verhindert (Tabelle I, Abb. 1). Das unterstützt die Auffassung, daß bei diesen Frauen zusätzlich zur Diät Insulin verabreicht werden sollte, um die geringfügigen metabolischen $\mathrm{Ab}$ weichungen zu korrigieren. Wie erwartet, waren Kinder von Patientinnen mit vaskulären Komplikationen, auch wenn es sich nur um Kalzifizierungen der pelvinen Gefäße handelte (Klasse E nach dem White-Schema), wegen der plazentaren Insuffizienz wachstumsretardiert (Tabelle I, Abb. 1). Diesem Phänomen wird in der Literatur keine Aufmerksamkeit gewidmet, da die Pathologie der pelvinen Gefäße unberücksichtigt bleibt und eine Zuordnung der Patientinnen zu den Klassen A bis C nicht stattfindet. Die Möglichkeit, eine fetale Makrosomie durch strenge Stoffwechselführung der Mutter zu vermeiden, wurde in Frage gestellt, weil zwischen der fetalen Makrosomie und der Ausprägung der maternalen Hyperglykämie und des fetalen Hyperinsulinismus keine Korrelation vorliegt $[9,11,13]$. Wir postulieren: Wenn, wie im Tierexperiment nachgewiesen [3], ein fetaler Hyperinsulinismus eine Hypoxie verursacht, kann diese fehlende Korrelation auf den fetalen Hyperinsulinismus zurückgeführt werden.

Schlüsselwörter: Diabetes mellitus und Schwangerschaft, fetale Makrosomie, Gestationsdiabetes, HyperglykämieHyperinsulinismus-Theorie, maximal tolerierte Insulindosis.

\section{Résumé}

Enfants macrosomes de mères diabétiques: causes et prévention

Dans cette étude on a comparé les poids de naissance de 431 enfants de mères diabétiques de la série de Milan $[14,15]$ aux poids de naissance d'un groupe contrôle [5]. Les moyennes et les distributions en percentiles des poids des enfants des mères avec un diabète gestationnel (classe A) et des mères diabétiques sans complication vasculaire (classe $\mathrm{B}$ et $\mathrm{C}$ ) ne sont pas très différents de ceux des nouveaux-nés contrôlés (tableau I, figure 1). Celà confirme l'indication dinique, fondée sur la théorie hyperglycémie-hyperinsulinémie [12] qui estime que l'on peut éviter la macrosomie fotale en équilibrant de façon stricte le métabolisme maternel. Dans cette série l'insuline était injectée à la dose maximale tolérée (MTD), attitude thérapeutique qui assure un contrôle métabolique excellent chez les mères $[14,15,16]$. Chez les multipares, les poids de naissance des enfants lors de la dernière grossesse étaient extrèmement inférieurs aux poids de naissance des enfants lors des grossesses précédentes (sans insuline à MTD) (tableau II). Nos résultats ne confirment pas l'hypothèse récente [18] que les diabétiques enceintes ayant un contrôle métabolique strict au cours de la grossesse donnent naissance en règle générale à des enfants hypotrophiques. On a également injecté l'insuline à MTD à des mères avec un diabète gestationnel et la macrosomie fotale a été évitée (tableau I, figure 1). Celà confirme l'opinion de ceux qui croient qu'un régime doit accompagner l'injection d'insuline pour corriger les anomalies métaboliques légères de ces patientes. Comme on s'y attendait, en raison de l'insuffisance placentaire, les enfants des patientes présentant des complications vasculaires, y compris celles qui ont des calcifications des vaisseaux pelviens (classe $\mathrm{E}$ de White), ont eu un retard de croissance (tableau I, figure 1). Le risque de retard de croissance intra-utérin dans la classe E n'a pas été remarqué dans la littérature, car, habituellement, on ne tient pas compte de la pathologie des vaisseaux pelviens et les patientes ne sont pas différentiées des classes $\mathrm{A}-\mathrm{C}$. La possibilité de prévenir la macrosomie fotale par un contrôle strict du diabète maternel est mise en question, en raison du manque de corrélation $[9,11,13]$ entre la macrosomie fotale et le degré d'hyperglycémie maternelle et l'hyperinsulinisme fœtal. Notre thèse: lorsque, l'hyperinsulinisme fœtal entraine une hypoxie, comme cela se produit en expérimentation animale [3], le manque de corrélation peut être, lui-même, secondaire à l'hyperinsulinisme fotal.

Mots-clés: Diabète gestationnel, diabète sucré au cours de la grossesse, dose maximale tolérée d'insuline, macrosomie fœtale, théorie hyperglycémie-hyperinsulinisme. 
Acknowledgements: We would like to thank Dr. E. FloRis for the statistical calculations, Mrs MoIRA MACPHERSON for reviewing the manuscript and we are grateful to the Novo Industri, Denmark for their support. Thanks are also due to Mrs. FranCESCA CAPILl for typing the manuscript.

\section{References}

[1] Battaglia FC: Fetal metabolism. In: VAN AssChe FA, WB RoBERTSON, M RENAER: Fetal growth retardation, p. 3. Churchill Livingstone, Edinburgh 1981

[2] Berglund G, R Zetterstrom: Infants of diabetic mothers. I. Foetal hypoxia in maternal diabetes. Preliminary report. Acta Paediatr 43 (1954) 368

[3] Carson BS, AF Philipps, MA Simmons, FC BattaGLIA, G MESCHIA: Effect of a sustained insulin infusion upon glucose uptake and oxygenation of the ovine fetus. Pediatr Res 14 (1980) 147

[4] Freinkel N, BE Metzger: Pregnancy as a tissue culture experience: The critical implications of maternal metabolism for fetal development. In: Pregnancy metabolism, diabetes and the fetus, Ciba Foundation Symposium 63 (new series), p. 3. Excerpta Medica, Amsterdam 1979

[5] Gagliardi L, CU Preve, C Cordero di Montezemolo, PG Mattone, A Piazza: Accrescimento intrauterino ed età gestazionale in un campione di 9774 casi. Ann Ostet Ginecol Med Perinat 96 (1975) 147

[6] Grasso S, N Saporito, a Messina, G Reitano: Serum insulin response to glucose and aminoacids in the premature infant. Lancet ii (1968) 755

[7] Grasso S, A Messina, G Distefano, R Vigo: Insulin secretion in the premature infant. Response to glucose and amino acids. Diabetes 22 (1973) 349

[8] Grasso S, G Palumbo, S Rugolo, A Cianci, G Tumino, G Reitano: Human fetal insulin secretion in response to maternal glucose and leucine administration. Pediatr Res 14 (1980) 782

[9] Leveno K J, JC Hauth, LC Gilstrap, PJ WhalLEY: Appraisal of "rigid" blood glucose control during pregnancy in diabetic women. Am J Obstet Gynecol 135 (1979) 853

[10] MiLleR HC, HM WiLSON: Macrosomia, cardiac hypertrophy, erythroblastosis and hyperplasia of the islands of Langherans in infants born to diabetic mothers. J Pediatr 23 (1943) 251

[11] Miller JM: A reappraisal of "tight control" in diabetic pregnancies. Am J Obstet Gynecol 147 (1983) 158

[12] Pedersen J: The pregnant diabetic and her newborn. Munksgaard, Copenhagen 1977
[13] Pedersen J, L Mølsted-Pedersen: Diabetes mellitus and pregnancy. The hyperglycaemia-hyperinsulinism theory and the weight of the newborn baby. In: Rodriguez RR, J VAlLANCE-Owen: Diabetes, p. 678. Excerpta Medica, Amsterdam 1971

[14] Roversi GD, M Gargiulo, U Nicolini, E PeDretti, A Marini, V Barbarani, P PenefF: A new approach to the treatment of diabetic pregnant women. Report of 479 cases seen from 1963 to 1975. Am J Obstet Gynecol 135 (1979) 567

[15] Roversi GD, M Gargiulo, U Nicolini, E FerRAZZI, E Pedretti, L Gruft, G Tronconi: Maximal tolerated insulin therapy in gestational diabetes. Diabetes Care 3 (1980) 489

[16] Roversi GD, M Gargiulo, U Nicolini, E PeDRETTI, E FERRAZZI, L GRUFT: Normalization of blood glucose in pregnant diabetics with the maximal tolerated dose (MTD) of insulin. J Perinat Med 8 (1980) 195

[17] Shelley HJ: The metabolic response of the fetus to hypoxia. J Obstet Gynaecol Br Cwlth 76 (1969) 1

[18] Sutherland HW, JF Pedersen, L Mølsted-PederSEN: Treatment of diabetic pregnancy with special reference to fetal growth. In: VAN AsSCHE FA, WB ROBERTSON, M RENAER: Fetal growth retardation, p. 197. Churchill Livingstone, Edinburgh 1981

[19] Tsang RC, J Ballard, C Braun: The infant of the diabetic mother: Today and tomorrow. Clin Obstet Gynecol 24 (1981) 125

[20] Widness JA, JB Susa, JF Garcia, DB Singer, P Seghal, W Oh, R Schwartz, HC Schwartz: Increased erythropoiesis and elevated erythropoietin in infants born to diabetic mothers and in hyperinsulinemic rhesus fetuses. J Clin Invest 67 (1981) 637

Received April 25, 1984. Revised October 31, 1985. Accepted January 6, 1986.

Sebastiano Grasso, M. D. Professor

Istituto di Anatomia ed Istologia Patologica Università di Catania Via Biblioteca, 4 I-95124 Catania, Italy 